\title{
The Key Role of the Blood Supply to Bone
}

\author{
Massimo Marenzana ${ }^{1}$, Timothy R. Arnett ${ }^{2 *}$ \\ ${ }^{1}$ Department of Bioengineering, Imperial College London and Kennedy Institute of Rheumatology, University of Oxford, UK; \\ ${ }^{2}$ Department of Cell and Developmental Biology, University College London, UK
}

The importance of the vascular supply for bone is well-known to orthopaedists but is still rather overlooked within the wider field of skeletal research. Blood supplies oxygen, nutrients and regulatory factors to tissues, as well as removing metabolic waste products such as carbon dioxide and acid. Bone receives up to about $10 \%$ of cardiac output, and this blood supply permits a much higher degree of cellularity, remodelling and repair than is possible in cartilage, which is avascular. The blood supply to bone is delivered to the endosteal cavity by nutrient arteries, then flows through marrow sinusoids before exiting via numerous small vessels that ramify through the cortex. The marrow cavity affords a range of vascular niches that are thought to regulate the growth and differentiation of hematopoietic and stromal cells, in part via gradients of oxygen tension. The quality of vascular supply to bone tends to decline with age and may be compromised in common pathological settings, including diabetes, anaemias, chronic airway diseases and immobility, as well as by tumours. Reductions in vascular supply are associated with bone loss. This may be due in part to the direct effects of hypoxia, which blocks osteoblast function and bone formation but causes reciprocal increases in osteoclastogenesis and bone resorption. Common regulatory factors such as parathyroid hormone or nitrates, both of which are potent vasodilators, might exert their osteogenic effects on bone via the vasculature. These observations suggest that the bone vasculature will be a fruitful area for future research.

Keywords: vasculature; skeleton; oxygen; hypoxia; osteoblast; osteoclast

Bone Research (2013) 3: 203-215. doi: 10.4248/BR201303001

\section{Introduction}

The role of the blood supply in the pathophysiology of bone deserves wider attention outside the orthopaedic community. This brief review focuses on selected topics of partic ular current interest. For more general covera ge of the bone vasculature, readers are referred to numerous exc ellent reviews (1-11).

\section{Anatomy and physiology of the blood supply to bone}

The channels and vessels in bone were observed by Van Leeuwenhoek and Havers in the late $17^{\text {th }}$ century and were confimed to be linked to blood supply by Albinus in the mid-18 th century. The importance of the blood

\footnotetext{
*Correspondence: Timothy R Amett

E-mail: t.amett@ucl.ac.uk

Received 13J une 2013; Accepted 22 J uly 2013
}

supply for bone was clearly recognized by surgeons in the $19^{\text {th }}$ century (1). In the $20^{\text {th }}$ century advances in orthopedics gave strong impetus to detailed functional studies of the bone vasculature, with pioneering contributions from Trueta and colleagues (1-2). Key studies by Brookes and colleagues demonstrated that the main blood supply of healthy long bones was derived from the principal nutrient arteries, which penetrate the cortex and perfuse the medullary sinusoids, then exit via multiple small veins. The cortical bone is perfused by a mixture of arterial blood originating from the main nutrient arteries as well as from the separate, smaller periosteal arteries. Thus, the flood flow in the long bones, at least from young adults, is largely centrifugal (ie, radiating outward after delivery to the marrow cavity) $(4,12)$ (Figures 1 and 2).

Healthy bone requiresa substantial blood flow to supply the requisite oxygen and nutrients, and to eliminate carbon dioxide, acid and other metabolic waste products. Estimates of the proportion of the cardiac output recei- 
ved directly by the skeleton range from about $5.5 \%$ to $11 \%$ (13-15). The rich perfusion of bone reflects not only the requirements of the bone cells (osteoblasts, osteocytes and osteoclasts), but also of the marrow (hematopoietic lineage cells, stromal cells and adipocytes), as well as endothelial cells. The long bones form from embryonic cartilage rudiments that are invaded by blood vessels and bone cells. The vascular supply of bone enables rapid growth, remodelling (including mechanical responsiveness) that is not possible in cartilage, which is essentially avascular. For a detailed consideration of the functional anatomy of the blood supply to bone during growth, maturity and regeneration, readers are referred to the comprehensive review of Wilson (2002) (7).

\section{Effect of oxygen on bone cell function}

It has long been recognized that bone growth (including endochondral ossification during development) and repair occur in association with a rich vascular supply. Conversely, impaiment of the blood supply is well-known to reduce growth and repair, cause bone loss and, ultimately, necrosis $(2-3,5,7-8,10-11,16)$. These observations are clearly consistent with the role of the vasculature in supplying nutrients, minerals and regulatory factors to bone. In recent years the influence of oxygen tension and hypoxia on bone function has become a major research focus.

Hypoxia occurs when the blood supply to tissues is reduced or disnupted. Oxygen tension $\left(\mathrm{pO}_{2}\right)$ in arterial blood is about $12.64 \mathrm{kPa}(12 \%)$; in venous and capillary blood it is about $5.32 \mathrm{kPa}(5 \%)$, approximately a quarter of that in atmospheric a ir. In normal tissues, median interstitial $\mathrm{pO}_{2}$ values range from about 3-9\% (17). Measurements of bone marrow aspirates from nomal human volunteer donors produced mean $\mathrm{pO}_{2}$ values of $6.6 \%$ (18). Cellular oxygen concentrations are nomally maintained within narrow physiological ranges. Cells respond

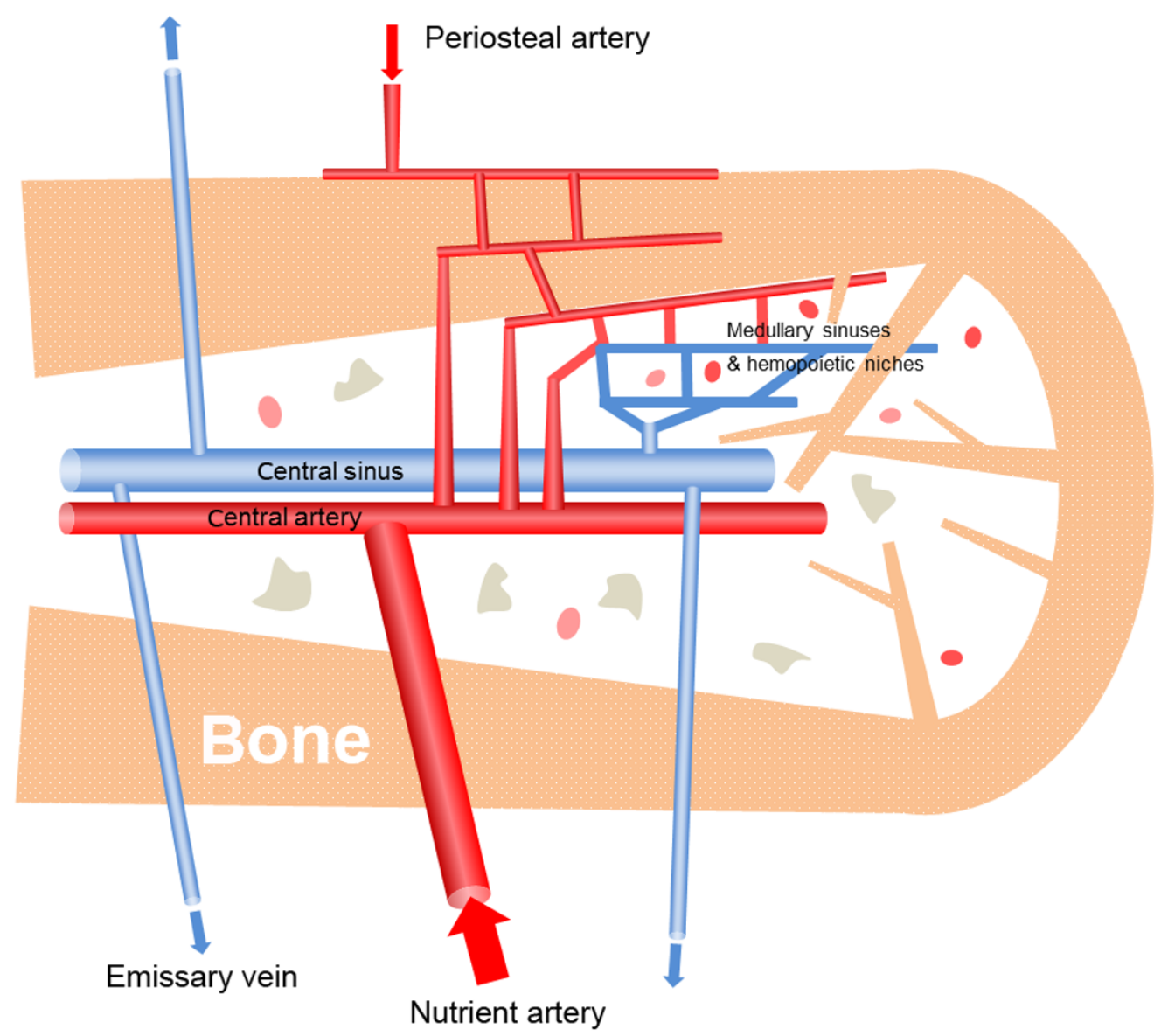

Figure 1 Schematic diagram showing general arrangement of the vascular supply to healthy adult bone. The main blood supply is derived from one or more nutrient arteries, which penetrate to the medulla and connect to the smaller periosteal arterial supply to enable perfusion of cortical bone. The arterial branches drain into arterio-venous sinuses in the medulla that support hematopoietic and stromal cells. Blood exits the medullary cavity via multiple small veins that penetrate the cortex. Thus, perfusion is predominantly centrifugal, at least in young adult bone. 


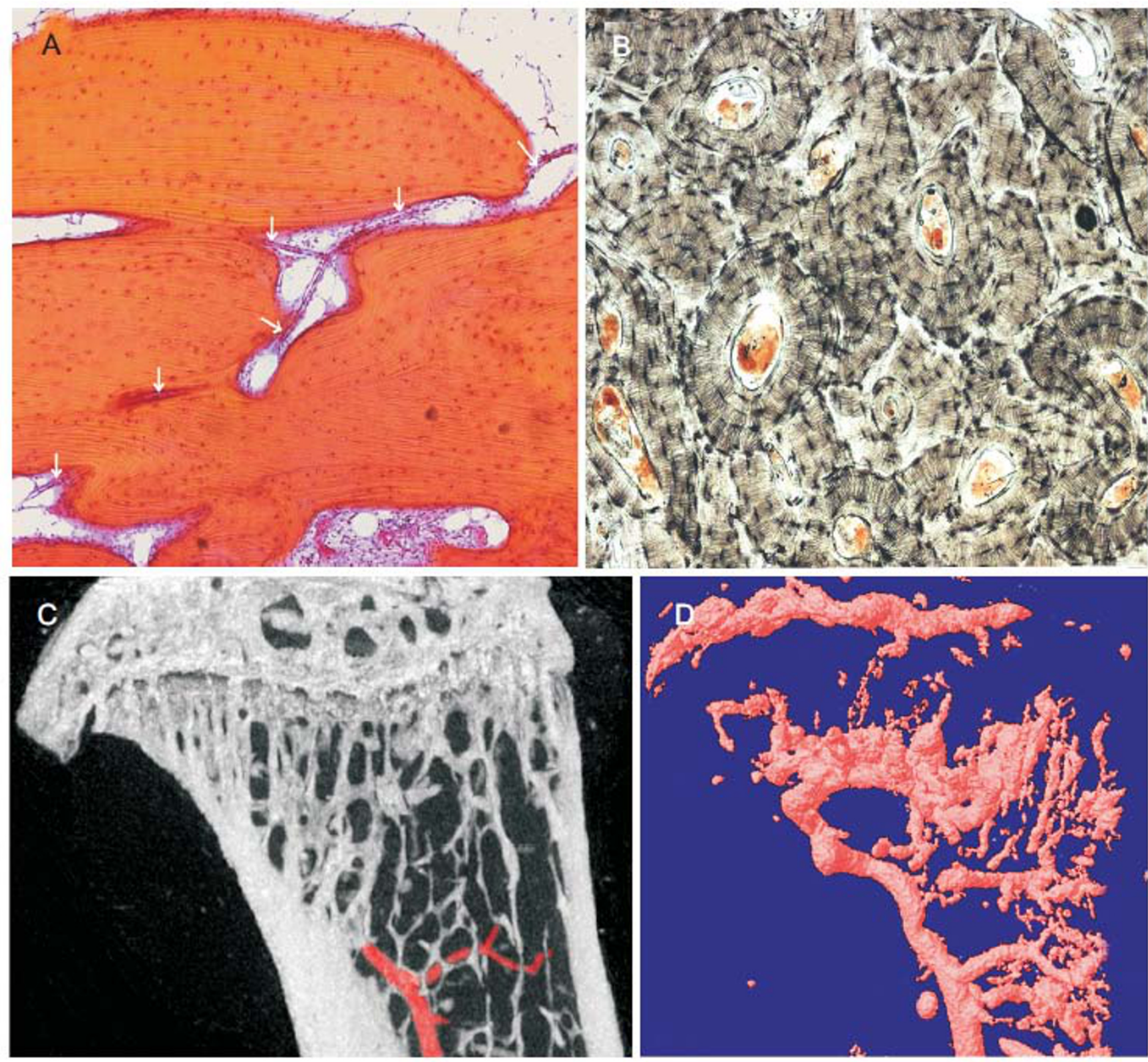

Figure 2 Bone vasculature. A: Light micrograph showing a thin-walled blood vessel (white arrows) penetrating lamellar cortical bone of adult human phalanx; longitudinal section, image width $1.5 \mathrm{~mm}$. B: Transverse section of human phalanx (ground with carbon black) showing Haversian systems with central blood vessel canals; image width $2 \mathrm{~mm}$. C: MicroCT scan of a sagittal section (2-D) of adult mouse tibia infused ex vivo with a radiopaque contrast agent showing the main medullary vessel (highlighted in red);image width $3.5 \mathrm{~mm}$. D: 3-D rendering of the vascular network and sinuses of the same tibia, rescanned by microCT after decalcifying the bone.

to changes in $\mathrm{pO}_{2}$ via the oxygen-dependent degradation of hypoxia-inducible transcription factors (HIFs). In the presence of oxygen, HIF-1a, and the closely related HIF-2a, are targeted by prolyl hydroxylases, which utilize molecular oxygen (with ascorbate as a co-factor) to selectively hydroxylate two conserved proline residues, which effectively tag HIF-a for polyubiquitination and proteasomal degradation. In the absence of sufficient oxygen, the prolyl hydroxylases are inactive and the proline residues on HIF-a remain unmodified; HIF-a is stabilized and heterodimerises with its transcription partner, HIF- $\beta$. The HIF heterodimer binds hypoxia response elements in promoter sequences of target genes, initiating transcription of hypoxia-regulated genes 
involved in a variety of cellular processes including angiogenesis (of which vascular endothelial growth factor, VEGF, is a key mediator), energy metabolism, cell proliferation/survival and $\mathrm{pH}$ control (19-20).

Experiments to test the direct effects of $\mathrm{pO}_{2}$ on osteoclast function yielded surprising results. Hypoxia was shown to strongly stimulate the number and size of osteoclasts formed in cultures of mouse marrow or human penipheral blood mononuclear cells, resulting in large increases in resorption pit fomation. Optimal osteoclast formation occured in $1-2 \% \mathrm{O}_{2}$ (with infrequent reoxygenation), but osteoclastogenesis and resorption were elevated even in cultures gassed with $0.2 \% \mathrm{O}_{2}(17$, 21-23). Conversely, hyperoxygenaemia decreases osteoclast formation and function (24). These responses are consistent with the known stimulatory action of hypoxia on other cells of the monocyte-macrophage lineage, and the adaptation of such cells to function in harsh, oxygen-deprived environments (17). Hypoxia is also associated with tissue acidosis, and reduced ambient $\mathrm{pH}$ is a well-known requirement for activation of mature osteoc lasts (17) (Figure 3).

In contrast, hypoxia has profound inhibitory effects on osteoblasts. Ambient $\mathrm{pO}_{2}$ levels below $2 \%$ result in nearcomplete abolition of bone formation by cultured primary osteoblasts (25) (Figure 3). The inhibition of osteogenesis in hypoxia was due to reductions in both growth and differentiation of osteoblasts, with inhibition of cell proliferation, collagen production and alkaline phosphatase. The inhibitory effect of hypoxia on collagen production may involve decreased expression and activity of the oxygen-dependent enzymes, prolyl 4-hydroxylase (a member of the same enzyme family as the oxygen-dependent prolyl hydroxylases that act upon HIFa) and lysyl oxidase, which are required for post-translational modific ation of collagen molecules. Interestingly, chronic hypoxia (unlike anoxia) does not increase cell death in osteoblasts, but rather induces a reversible state of quiescence (25). These studies also indicated that high (supraphysiological) $\mathrm{pO}_{2}$ levels a re osteogenic and support the notion that bone formation is dependent on a rich vascular supply.

\section{Vascularniches in bone}

The fine anatomy of the vasculature in bone requires specialist techniques to study histologically, not only because of the technical difficulties presented by the bone itself, but also because the vessels and sinusoids are mostly very delic ate, with very thin walls, or consisting only of endothelial cells (26). The marrow is a site for ha ematopoiesis, as well as acting as a reserve for stromal cells that could differentiate into osteoblasts, fibroblasts and the adipocytes that make up the bulk of its volume. Although the mean $\mathrm{pO}_{2}$ in healthy marrow may be in the range of $6-7 \%(18)$, mathematical models predict that $\mathrm{pO}_{2}$ may fall as low as $1 \%$ in the mic roenvironments most distant from capillaries (27). In the absence of clear experimental evidence, such hypoxic sites are postulated to provide niches favourable to the maintenance of undifferentiated haematopoietic stem cells $(20,28)$. Although experimental evidence shows that hypoxia actually stimulates osteoclast formation, at least from mixed marrow or circulating mononuclear cells $(17,22)$, this concept is consistent with the maintenance of quiescent, undifferentiated cells of the stromal lineage (17, 25, 29-30).

Another vasc ular mic roenvironment that has attracted attention in recent years is the 'bone remodeling compartment' or 'canopy', first described by Hauge in 2001. This canopy is formed by flattened, osteoblast-like cells at an early differentiation stage, similar to bone lining cells; it is proposed to be a site in which bone resorption formation take place in regulated ('coupled') manner (31-33). A related concept was also put forward by Parfitt (6). Such compartments, although tec hnic ally diffic ult (or impossible) to access for real-time physiological analysis, could serve to provide optimal conditions, including $\mathrm{pO}_{2}$ and $\mathrm{pH}$, for bone resomtion and bone formation $(17,32-33)$.

\section{Role of vasculature in bone regeneration and fracture healing}

Orthopaedic surgeons have long appreciated the role of the blood supply in bone growth and healing (2-3). The trauma of a fracture or other major bone injury also damages the blood supply, resulting in local hypoxia, which may be mainta ined by the subsequent inflammation (34). In rabbits, for example, $\mathrm{pO}_{2}$ in the fracture hematoma is $<1 \%$ (35) and in the medullary cavity following osteotomy between about 1-3\%(36). The HIF-a pathway, which is activated in hypoxia, is reported to be a key mechanism for coupling bone growth to angiogenesis, via increased expression of VEGF, the major angiogenic cytokine expressed by hypoxic osteoblasts. Mice selectively overexpressing HIFa in their osteoblasts had high levels of VEGF expression and extremely dense, highly vascularised bones (37-38). These mice also produced more bone in response to tibial osteotomy and distraction osteogenesis, whereas mice lacking HIF-1a in osteoblasts had impaired VEGF-dependent angiogenesis and bone healing (39). The role of HIFs in osteogenesis may be quite complex, however. A recent report indi- 
cates that HIF-1a may also activate expression of sclerostin (the key bone-specific inhibitor of Wnt signaling) in osteoblasts, thus potentially reducing osteogenesis (40). The VEGF homologue, PIGF (placental growth factor), which acts through the VEGF receptor, also appears to play a significant role in promoting fracture healing (34). VEGF stimulates the regrowth of blood vessels into the injury site, so that oxygen and nutrient levels can begin to retum to nomal values.

The general pattem of bone cell activity following fracture or osteotomy is broadly consistent with the known responses of osteoblasts and osteoclasts to changes in $\mathrm{pO}_{2}$ : the early hypoxic phase favours osteoclast recruitment, whilst inhibiting osteoblasts (which may survive locally in a quiescent state), whereas revascularisation will progressively favour osteoblast function (proliferation, differentiation and bone fomation). Osteoblast precursors could also move into developing and fractured bones along with invading blood vessels (41). Bone microdamage, induced by fatigue loading, has also been shown to increase local vascularity and blood perfusion, probably as a repair mechanism to reconstruct a disnupted lacuno-canalicular network (42). It is worth noting that application of early or delayed functional loading has been shown to respectively inhibit or stimula te neovascular growth in a rat model of large bone defect regeneration (43). This suggests that biomechanical stimulation could modulate vascular growth and remodelling during bone repair, partially overiding the nomal sequence of cellular responses described above.

\section{The role of angiogenesis in bone metabolism and blood perfusion}

Bone perfusion by oxygen and nutrients is the product of the vascular tone, which regulates blood flow as discussed above, and the density of the vessels. The densi-
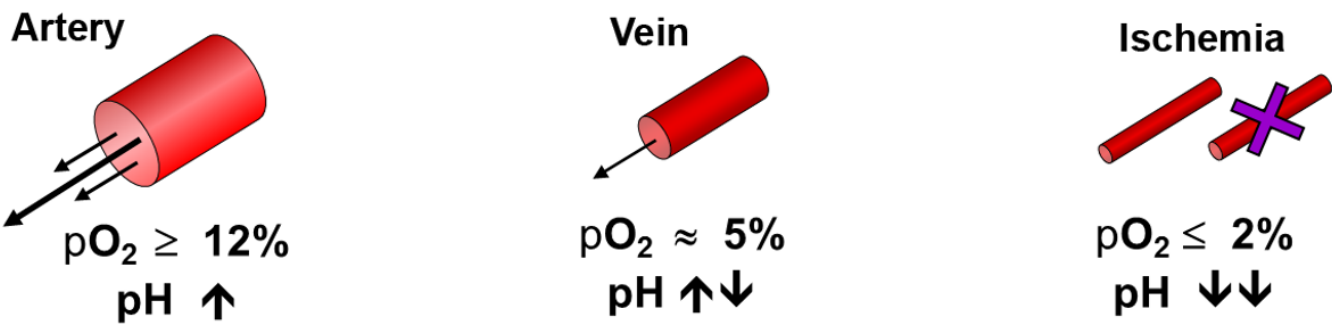

$N O R \quad M O X \quad A$

$\begin{array}{llllllllllllllllll}H & Y & P & O & X & \text { I } & A\end{array}$

\section{०णनणण0}

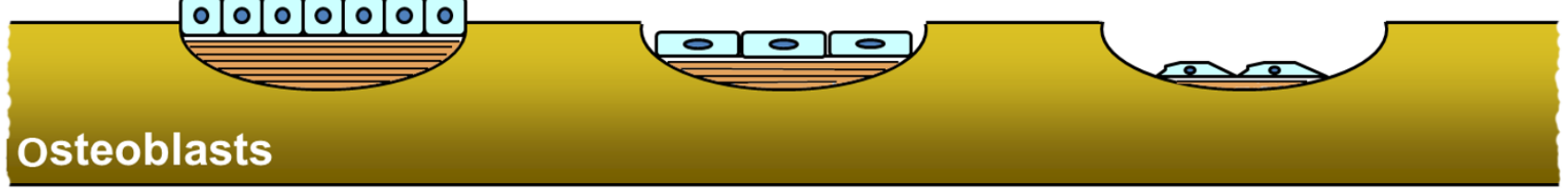

\section{Net bone formation $\longrightarrow$ Bone maintenance $I \longrightarrow$ Severe bone loss}

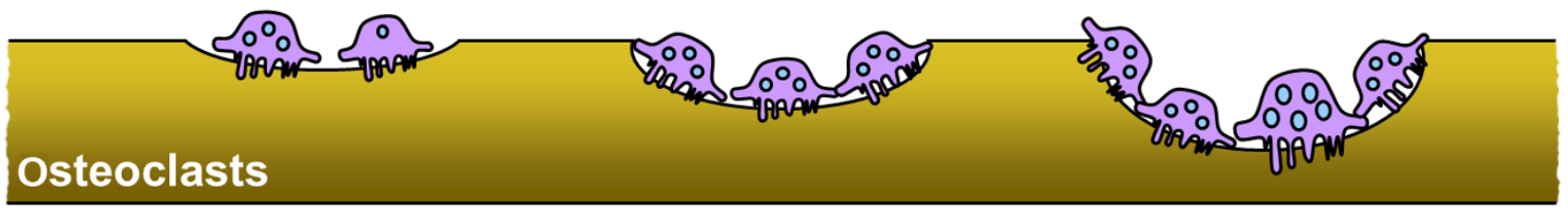

Figure 3 Schematic diagram summarising the key effects of oxygen on bone cell function. Osteoblast function (proliferation, differentiation and collagen production) are inhibited in hypoxia; osteoblasts enter a quiescent state. In contrast, hypoxia stimulates the formation of osteoclasts from mononuclear precursor cells (in the presence of RANKL and M-CSF), resulting in increased bone resorption. The negative impact of hypoxia is exacerbated by the accompanying acidosis, which blocks matrix mineralisation and stimulates mature osteoclasts to resorb. 
ty and in general the structure of the vascular bed depends on the regulation of local angiogenic and vasculogenic factors. Angiogenesis has been studied much more extensively in relation to the endochondral ossification process and bone repair, readers are referred to excellent recent reviews on this topic (10-11, 44-45).

The pivotal factor linking angiogenesis to bone remodelling is VEGF, which, when overexpressed in cells of the osteoblast lineage in vivo, leads to a high bone mass phenotype associated to marrow fibrosis and increased number of blood vessels (46). These effects appear to be secondary, at least in part, to activation of Wnt/ beta-catenin signaling in osteoblasts. This is consistent with a role of Wnt-1 signaling in the angiogenic response, which ameliorated blood perfusion in ischaemic limbs (47). Conversely, mice that lack VEGF in osteoprogenitors display a reduced bone mass phenotype with increased bone marrow fat (48).

HIF-1a is the most important transcription factor regulating VEGF production by bone cells in response to hypoxia $(34,49)$. Importantly, VEG F expression, as expected, is increased in mutant bones lacking $\mathrm{VHL}$, which increases activated HIF-1a activity in cells of the osteoblast lineage (37). Therefore, it is reasonable to hypothesize that VEG F could be responsible for the increased number and/or size of blood vessels in these mutants (19), although this possibility has still to be experimentally tested.

It is reported that bone mass accrual induced by intemittent $\mathrm{PTH}$ in mice is not accompanied by an angiogenic response in the bone marrow vascular network, although blood vessels were observed to relocate closer to bone formation sites. The osteogenic effect was blunted by blocking VEGF (50). It is not clear from these studies whether VEG F was required for the relocation of marrow vessels (50), or to mediate the vasorelaxant effect of PTH (51).

\section{Pathological changes to bone blood supply associated with aging or systemic disorders}

The general association between ageing, vascular dysfunction and bone loss was not widely recognised until quite recently $(8,10,52)$. The oxygen consumption of human bone declines with age, accompanied by decreased vascular conductance (53). Doppler ultrasound measurements showed that femoral artery blood flow wasabout $30 \%$ lower in old men (average age 64 years), compared with young men (average age 28 years), whereas vascular resistance was a bout $50 \%$ higher (54). Elderly women with osteoporosis are reported to have reduced femoral blood flow, measured by magnetic resonance perfusion imaging, in association with inc reased marrow fat compared with non-osteoporotic subjects (55). Decreased femoral blood flow, measured using radiolabelled microspheres, has also been reported in aged male rats, correlating with reduced bone strength (56) and reduced endothelium-dependent vasodilation (57). In female rats, magnetic resonance imaging showed that vertebral blood flow was reduced 8 weeks after ovariec tomy (a model for post-menopausal osteoporosis), a longside decreased bone mineral density (58).

An important contributor to reduced systemic blood flow in the elderly is the increased vascular stiffness and resistance due to calcification of the muscle walls of large vessels. There is a well-known, reciprocal relationship between mineral in bone and mineral deposition in major blood vessels (59-61), which can be viewed as a kind of 'vicious cycle'. Decreased perfusion of bone will tend to lead to decreased medullary $\mathrm{pO}_{2}$, which, as noted above, will favor increased osteoclastic resorption and reduced bone formation. The resulting chronic net efflux of calcium from the bones into the blood supply might, in tum, be expected to favor mineralisation of vessel walls. Ex-vivo studies of human long bones have suggested that, with age, decreasing medullary perfusion may to some extent be compensated by an increased periosteal blood supply (5). The responses of bone cells to changes in $\mathrm{pO}_{2}$ may also help to explain why the diameter of long bones slowly increases with age, a lbeit accompanied by thinner cortices (i.e., due to increased endosteal resorption, plus increased periosteal forma tion).

Essential hypertension is a key reversible risk factor in cardiovascular disease, which is strongly associated with aging (62). Hypertension has been shown to correlate with reduction in BMD in women (63-65) and a nimals (66) and has been proposed as a risk factor for osteoporotic fractures (67). The stiffening of the blood vessels characterising hypertension is caused by several factors, including imbalance of osteotropic homones and endothelial dysfunction with reduced NO bioavailabilty and impaired vasodilation (61). Antihypertensive drugs have hemodynamic and physiologic effects that attenuate these vascular disease processes, but are class-specific (e.g., anticoagulants, beta-blockers, and calc ium channel blockers) and have provided generally beneficial effects to bone mass (68-71).

A number of common systemic disorders can potentially impair vascular perfusion of bone, with associated bone loss. These include diabetes $(61,72-73)$, chronic obstructive pulmonary diseases (74-76) and anaemias 
(77-78). Smoking, which delivers the va soc onstric tor, nic otine, is a lso strongly associated with bone loss (79-80). The role of disuse or decreased mechanical loading in bone loss related to reduced perfusion is discussed in the following section.

\section{Mechanoadaptation of bone and the blood supply}

The beneficial effect of exercise on maintaining bone homeostasis with aging has been shown to be associated with alterations in endothelium-dependent vasodilatation and structure of rat skeletal muscle arterioles, which, in tum, affect limb and bone perfusion (81). Increased bone vessel function (NO-mediated vasodilation of bone resistance arteries) has been associated with increased trabecular bone volume induced by endurance training in rats (82). Besides increasing vessel function, exercise also causes an elevation in the number and density of intra osseous vessels in rats, which has been attributed to an elevation in the angiogenic factor VEGF (83).

Conversely, disuse-induced bone loss caused by bedrest (84), hind limb unloading (85), neurec tomy and spinal cord injury (86), have been associated with altered indexes of bone blood perfusion. Although the adaptation of bone to mechanical strain (beyond or below customary levels) seems to clearly involve changes in bone perfusion and vessel function, the physical and molecular mechanisms linking are not fully understood. Given the key role of Wnt/beta-catenin signaling on mechanoadaptation and osteogenesis (87), further investigation is needed to relate this important pathway to bone blood flow.

Elevation of the intramedullary pressure (IMP) by intramedullary fluid pumps (88-90), or by dynamic skeletal muscle stimulation (91), can strongly affect bone mass and quality, even independent of direct stra in applied to bone. This phenomenon is also observable after venous occlusion (92-94), hyperhydration (95), mic rogravity (85, 96) and hypertension (97).

Interstitial fluid flow across the lac uno-canalic ular porosity, driven by dynamic mechanical strain of the poroelastic bone matrix and oscillating elevation in the IMP, is considered the most likely stimulus for osteocytic mechanosensing (98). Although, it has long been known that IMP pressure is about one fourth of the systemic arterial pressure and IMP depends on the total blood flow entering the bone and the total blood flow leaving it and has a pulsatile regime synchronous with the arterial blood pressure and respiration (99). Theoretical (100) and experimental (101) results suggest that local or systemic vascular pressure itself does not enhance solute transport within the bone lacuno-canalic ular porosity. This, however, does not exclude that the changes in bone perfusion may either interact with the osteocytic mechanoadaptive response indirectly, by altering the composition of the milieu of the bone interstitial fluid (which is an ultrafiltra te of blood), or by changing the mechanical environment of the bone marrow, thereby stimulating the bone cells in direct contact with the marrow, rather than the osteocytes (99). This is supported by the recent finding that elevation in IMP is able to stimulate bone adaptation also without the contribution of osteocytes, which were genetic ally ablated (88).

Whether and how changes in mechanical loading and/or IMP may affect bone blood circulation and the tone of the intramedullary blood vessel is not clear (99), but it is likely that muscle contraction plays a role through the modulation of vascular resistance regulation the flow of blood exiting bone (102-103). Further research in this area is required to understand whether skeletal blood perfusion and mechanoadaptation to exerciseinduced bone strain may induce synergistic effects on bone formation.

\section{Physiological and phamacological regulators of bone perfusion}

A number of seminal studies dating from the late 1970s on the perfusion pressure of the nutrient artery in the tibia of dogs have demonstrated that the vascular bed of bone actively responds to vasoconstrictors and vasodilators. These factors included NO (104), agonists and antagonists of the alpha and beta adrenergic receptors $(15,105-107)$ and modulators of the CAMP or CGMP signaling (104), which are present in endothelial and smooth muscle cells (eg, acetylcholine, adrenaline, methoxamine, alpha-blockers, propranolol, iso proterenol, dibutyryl cyclic AMP, 8-bromo-cyclic GMP), and have the ability to regulate systemic blood pressure and/or cardiac output.

However, only recently has the relationship between blood flow regulators and bone metabolism been demonstrated. Clinical and experimental observations appear to support a general model in which factors that decrease systemic blood pressure and increase blood perfusion induce beneficial effects on bone mass and vice versa (ie, vasoactive agents, which increase vascular tone and decrease blood flow are associated with bone loss). The best known endogenous modulator of the vascular tone is Nitric Oxide (NO), which is essential for the maintenance of a functional cardiovascular system (108). Aging has been shown to reduce endothelium- 
dependent vasodilation, and NO bioavailability in rats, which was associated with reduced skeletal blood flow (57). Hind limb blood flow in rodents has been shown to depend largely on NO and is modulated to a lesser extent by the endothelium-derived hyperpolarising factor (109). There is strong evidence that supplementation of NO donors such as nitroglycerine (110-114) and isosorbide mononitrate (114-115) increase bone mass in animals and osteoporotic patients, although there are also some conflicting studies in humans (116-117). Whether the osteoanabolic action of NO in bone is mediated indirectly by endothelium-controlled blood perfusion, or whether it also has signific ant direct actions on bone cells, is still not known. The effects of NO on bone cell function are not very clear-cut: biphasic effects on the function of both osteoblasts and osteoclasts have been reported (118). The role of nitric oxide synthases in bone also appears to require further clarific ation. Recent studies indicate that endothelial nitric oxide synthase (eNOS), previously thought to be important for NO production in bone, may not be required for the responses of bone and bone cellsto mechanical loading (119-121). Thus, other forms of NOS expressed by bone and vascular cells (neural NOS and inducible NOS) might play signific ant roles in NO synthesis.

Studies on the skeletal effects of other drugs used in the treatment of cardiovascular disease, including oral anticoagulants, beta-blockers, and calcium channel blockers, have yielded conflicting results (67-71, 122). Nevertheless, since drugs used to treat hypertension can increase systemic blood flow, further clinic al and experimental research should be waranted into their potential beneficial effects on bone perfusion. It has been recently shown that phosphodiesterase 5 inhibitors, such as sildenafil, which are potent vasodilators used to treat erectile dysfunction, increase fracture healing in mice (123).

Vasoconstrictors, on the other hand, may have negative impacts on bone. For example, increased levels of endothelin (ET)-1, a potent endogenous vasoconstric tor linked to increased cardiovascular risk, are associated with the menopause and osteopenia (124-125). The powerful vasoconstrictor nicotine has been shown to inhibit bone regeneration in a rabbit model of distraction osteogenesis (126). Interestingly, this inhibitory effect of nicotine on bone formation and perfusion was associated with increased angiogenesis, which was unable to counteract the reduction in blood flow (127).

In addition to well known vasoactive agents, a number of other endogenous factors recognised as major regulators of bone mass have been shown to induce potent vasotonic effects. In line with this notion, factors which increase bone formation such as PTH (128), PGE2 (129) and estrogen (130-131) are potent vasodilators and increase bone blood flow, while factors that inhibit bone formation such as glucocorticoids also decrease vas cularity and skeletal perfusion (132-133). It is c urrently not clear whether the vasc ular effects associated with these factors ultimately play a significant role in their actions on bone. This is an area of active current research.

It has been known since the 1920s that administration of exogenous PTH causes systemic hypotension and increased regional blood flow $(130,134-135)$. This effect is mediated by a potent vasorelaxant effect of $\mathrm{PTH}$ on vascular smooth muscle cells (SMC) (136); overexpression of PTH/PTHrP type 1 receptor in SMC reduces systemic blood pressure (137). PTH-induced vasorelaxation in bone blood vessels (ex vivo) has been linked with its osteoanabolic activity (51). A study by Prisby and colleagues showed that showed that PTH caused dilation of bone arteries and that was partly mediated by VEG $F$ (51), which also functions as a vasodilator, in a ddition to its better-known role in angiogenesis (138). Our own recent experimental data are in full agreement with these results. We have shown that blocking the vasorelaxant effect of $\mathrm{PTH}$ by an inhibitor of NO synthase (L-NAME) partially blunted its osteoanabolic action in mice (139).

A fascinating aspect of the mechanism of action of $\mathrm{PTH}$ and $\mathrm{PGE}_{2}$ is the fact that while they both induce a potent anabolic effect on bone when dosed intermittently (eg, daily) (140-141), they become catabolic when administered by continuous sow release (142-144). At present, there is no clear experimental explanation for this time-dependent action. However, if acute vasorelaxation plays an important role in the mechanism of action of $P G E_{2}$ and $P T H$, it could be speculated that an adaptation similar to tachyphylaxis may take place in the cardiovascular system during continuous dosing, which may abolish the initial acute vasorelaxation response.

It is also well known that estrogen can boost blood flow (145-146). Deprivation of endogenousestrogen (130, 147$148)$ and synthetic estrogen supplementation (131, 149150) have opposite potent vasoactive effects, although the relationship between the osteogenic and cardiovascular effects remains to be fully elucidated.

\section{Conclusions}

Considerable progress has been made towards better understanding the role of the vasculature in the pathophysiology of bone. Clearly, this will remain a fruitful topic for research because of the strong links to common bone disorders. Some key practical questions for 
the future include: 1) What is the role of hypoxia and HIF in bone growth and repair? 2) To what extent do the osteoanabolic actions of agents such as PTH, Wnt proteins and nitric oxide donors depend on vascular responses? 3) Are the cardiovascular system and vascular tone involved in bone mass homeostasis? 4) To what extent do the osteocatabolic actions of glucocortic oids depend on vascular responses? A better understanding of the basic physiological mechanisms linking vascular function to bone metabolism has the potential to unravel new pharmacological approaches to activate bone growth and accelerate fracture healing.

\section{References}

1 Trueta J, Harrison MH. The normal vascular anatomy of the femoral head in adult man. J Bone Joint Surg Br. 1953;35-B:442461.

2 Trueta J, Morgan JD. The vascular contribution to osteogenesis. I. Studies by the injection method. J Bone Joint Surg Br. 1960;42-B: 97-109.

3 Trueta J. Blood supply and the rate of healing of tibial fractures. Clin Orthop Relat Res. 1974:11-26.

4 Brookes M, Harrison RG. The vascularization of the rabbit femur and tibio-fibula. J Anat. 1957;91:61-72.

5 Bridgeman G, Brookes M. Blood supply to the human femoral diaphysis in youth and senescence. J Anat. 1996;188:611-621.

6 Parfitt AM. The mechanism of coupling: a role for the vasculature. Bone. 2000;26:319-323.

7 Wilson JW. Blood supply to developing, mature, and healing bone//Sumner-Smith G (ed), Bone in Clinical Orthopedics. 2nd ed. Stuttgart New York: Georg Thieme Verlag, 2002:23-116.

8 Laroche M. Intraosseous circulation from physiology to disease. Joint Bone Spine. 2002;69:262-269.

9 McCarthy I. The physiology of bone blood flow: a review. J Bone Joint Surg Am. 2006;88 Suppl 3:4-9.

10 Brandi ML, Collin-Osdoby P. Vascular biology and the skeleton. J Bone Miner Res. 2006;21:183-192.

11 Portal-Núñez S, Lozano D, Esbrit P. Role of angiogenesis on bone formation. Histol Histopathol. 2012;27:559-566.

12 Brookes M. Blood supply of long bones. Br Med J. 1963;2:10641065 .

13 Cumming JD, Nutt ME. Bone-marrow blood flow and cardiac output in the rabbit. J Physiol. 1962;162:30-34.

14 Ray RD, Kawabata M, Galante J. Experimental study of peripheral circulation and bone growth. An experimental method for the quantitative determination of bone blood flow. 3. Clin Orthop Relat Res. 1967;54:175-185.

15 Gross PM, Heistad DD, Marcus ML. Neurohumoral regulation of blood flow to bones and marrow. Am J Physiol. 1979;237:H440H448.

16 Enjolras O, Chapot R, Merland JJ. Vascular anomalies and the growth of limbs: a review. J Pediatr Orthop B. 2004;13:349-357.

17 Arnett TR. Acidosis, hypoxia and bone. Arch Biochem Biophys. 2010;503:103-109.

18 Harrison JS, Rameshwar P, Chang V, Bandari P. Oxygen saturation in the bone marrow of healthy volunteers. Blood. 2002;99:394.

19 Schipani E, Maes C, Carmeliet G, Semenza GL. Regulation of osteogenesis-angiogenesis coupling by HIFs and VEGF. J Bone Miner Res. 2009;24:1347-1353.

20 Suda T, Takubo K, Semenza GL. Metabolic regulation of hematopoietic stem cells in the hypoxic niche. Cell Stem Cell. 2011;9:298310.

21 Arnett TR, Gibbons DC, Utting JC, Orriss IR, Hoebertz A Rosendaal M, Meghii S. Hypoxia is a major stimulator of osteoclast formation and bone resorption. J Cell Physiol. 2003;196:2-8.

22 Utting JC, Flanagan AM, Brandao-Burch A, Orriss IR, Arnett TR Hypoxia stimulates osteoclast formation from human peripheral blood. Cell Biochem Funct. 2010;28:374-380.

23 Dandajena TC, Ihnat MA, Disch B, Thorpe J, Currier GF. Hypoxia triggers a HIF-mediated differentiation of peripheral blood mononuclear cells into osteoclasts. Orthod Craniofac Res. 2012;15: $1-9$.

24 Hadi HA, Smerdon GR, Fox SW. Hyperbaric oxygen therapy suppresses osteoclast formation and bone resorption. J Orthop Res. 2013 July 22. [Epub ahead of print]

25 Utting JC, Robins SP, Brandao-Burch A, Orriss IR, Behar J, Arnett TR. Hypoxia inhibits the growth, differentiation and boneforming capacity of rat osteoblasts. Exp Cell Res. 2006;312:16931702.

26 Roche B, David V, Vanden-Bossche A, Peyrin F, Malaval L, Vico L, Lafage-Proust $\mathrm{M}-\mathrm{H}$. Structure and quantification of microvascularisation within mouse long bones: what and how should we measure? Bone. 2012;50:390-399.

27 Chow DC, Wenning LA, Miller WM, Papoutsakis ET. Modeling $\mathrm{pO}(2)$ distributions in the bone marrow hematopoietic compartment. II. Modified Kroghian models. Biophys J. 2001;81:685-696.

28 Eliasson P, Jönsson JI. The hematopoietic stem cell niche: low in oxygen but a nice place to be. J Cell Physiol. 2010;222:17-22.

29 Yang DC, Yang MH, Tsai CC, Huang TF, Chen YH, Hung SC. Hypoxia inhibits osteogenesis in human mesenchymal stem cells through direct regulation of RUNX2 by TWIST. PloS One. 2011; 6:e23965.

30 Xu N, Liu H, Qu F, Fan J, Mao K, Yin Y, Liu J, Geng Z, Wang Y, Hypoxia inhibits the differentiation of mesenchymal stem cells into osteoblasts by activation of Notch signaling. Exp Mol Pathol. 2013;94:33-39.

31 Hauge EM, Qvesel D, Eriksen EF, Mosekilde L, Melsen F. Cancellous bone remodeling occurs in specialized compartments lined by cells expressing osteoblastic markers. J Bone Miner Res. 2001;16:1575-1582.

32 Eriksen EF, Eghbali-Fatourechi GZ, Khosla S. Remodeling and vascular spaces in bone. J Bone Miner Res. 2007;22:1-6. 
33 Kristensen HB, Andersen TL, Marcussen N, Rolighed L, Delaisse JM. Increased presence of capillaries next to remodeling sites in adult human cancellous bone. J Bone Miner Res. 2013;28:574-585.

34 Maes C, Carmeliet G, Schipani E. Hypoxia-driven pathways in bone development, regeneration and disease. Nat Rev Rheumatol. 2012;8:358-366

35 Brighton CT, Krebs AG. Oxygen tension of healing fractures in the rabbit. J Bone Joint Surg Am. 1972;54:323-332.

36 Aro H, Eerola E, Aho AJ, Niinikoski J. Tissue oxygen tension in externally stabilized tibial fractures in rabbits during normal healing and infection. J Surg Res. 1984;37:202-207.

37 Wang Y, Wan C, Deng L, Liu X, Cao X, Gilbert SR, Bouxsein ML, Faugere M-C, Guldberg RE, Gerstenfeld LC, Haase VH, Johnson RS, Schipani E, Clemens TL. The hypoxia-inducible factor alpha pathway couples angiogenesis to osteogenesis during skeletal development. J Clin Invest. 2007;117:1616-1626.

38 Wang Y, Wan C, Gilbert SR, Clemens TL. Oxygen sensing and osteogenesis.Ann N Y Acad Sci. 2007;1117:1-11.

39 Wan C, Gilbert SR, Wang Y, Cao X, Shen X, Ramaswamy G, Jacobsen KA, Alaql ZS, Eberhardt AW, Gerstenfeld LC, Einhorn TA, Deng L, Clemens TL. Activation of the hypoxia-inducible factor-1alpha pathway accelerates bone regeneration. Proc Natl Acad Sci U S A. 2008;105:686-691.

40 Chen D, Li Y, Zhou Z, Wu C, Xing Y, Zou X, Tian W, Zhang C. HIF-1a Inhibits Wnt Signaling Pathway by Activating Sost Expression in Osteoblasts. PloS One. 2013;8:e65940.

41 Maes C, Kobayashi T, Selig MK, Torrekens S, Roth SI, Mackem S, Carmeliet G, Kronenberg HM. Osteoblast precursors, but not mature osteoblasts, move into developing and fractured bones along with invading blood vessels. Dev Cell. 2010;19:329-344.

42 Muir P, Sample SJ, Barrett JG, McCarthy J, Vanderby R Jr, Markel MD, Prokuski LJ, Kalscheur VL. Effect of fatigue loading and associated matrix microdamage on bone blood flow and interstitial fluid flow. Bone. 2007;40:948-956.

43 Boerckel JD, Uhrig BA, Willett NJ, Huebsch N, Guldberg RE. Mechanical regulation of vascular growth and tissue regeneration in vivo. Proc Natl Acad Sci U S A. 2011;108:E674-E680.

44 Chim SM, Tickner J, Chow ST, Kuek V, Guo B, Zhang G, Rosen V, Erber W, Xu J. Angiogenic factors in bone local environment. Cytokine Growth Factor Rev. 2013;24:297-310.

45 Gerber HP, Ferrara N. Angiogenesis and bone growth. Trends Cardiovasc Med. 2000;10:223-228.

46 Maes C, Goossens S, Bartunkova S, Drogat B, Coenegrachts L, Stockmans I, Moermans K, Nyabi O, Haigh K, Naessens M, Haenebalcke L, Tuckermann JP, Tjwa M, Carmeliet P, Mandic V, David J-P, Behrens A, Nagy A, Carmeliet G, Haigh JJ. Increased skeletal VEGF enhances beta-catenin activity and results in excessively ossified bones. EMBO J. 2010;29:424-441.

47 Gherghe CM, Duan J, Gong J, Rojas M, Klauber-Demore N, Majesky M, Deb A. Wnt1 is a proangiogenic molecule, enhances human endothelial progenitor function, and increases blood flow to ischemic limbs in a HGF-dependent manner. FASEB. 2011;
25:1836-1843.

48 Liu Y, Berendsen AD, Jia S, Lotinun S, Baron R, Ferrara N, Olsen BR. Intracellular VEGF regulates the balance between osteoblast and adipocyte differentiation. J Clin Invest. 2012;122:3101-3113.

49 Riddle RC, Khatri R, Schipani E, Clemens TL. Role of hypoxiainducible factor-1alpha in angiogenic-osteogenic coupling. J Mol Med Berl Ger. 2009;87:583-590.

50 Prisby R, Guignandon A, Vanden-Bossche A, Mac-Way F, Linossier MT, Thomas M, Laroche N, Malaval L, Langer M, Peter ZA, Peyrin F, Vico L, Lafage-Proust MH. Intermittent PTH (1-84) is osteoanabolic but not osteoangiogenic and relocates bone marrow blood vessels closer to bone-forming sites. J Bone Miner Res. 2011;26:2583-2596

51 Prisby R, Menezes T, Campbell J. Vasodilation to PTH (1-84) in bone arteries is dependent upon the vascular endothelium and is mediated partially via VEGF signaling. Bone. 2013;54:68-75.

52 Alagiakrishnan K, Juby A, Hanley D, Tymchak W, Sclater A. Role of vascular factors in osteoporosis. J Gerontol A BiolSci Med Sci. 2003;58:362-366.

53 Dinenno FA, Jones PP, Seals DR, Tanaka H. Limb blood flow and vascular conductance are reduced with age in healthy humans: relation to elevations in sympathetic nerve activity and declines in oxygen demand. Circulation. 1999;100:164-170.

54 Dinenno FA, Tanaka H, Stauffer BL, Seals DR. Reductions in basal limb blood flow and vascular conductance with human ageing: role for augmented alpha-adrenergic vasoconstriction. J Physiol. 2001;536:977-983.

55 Griffith JF, Yeung DKW, Tsang PH, Choi KC, Kwok TCY, Ahuja AT, Leung KS, Leung PC. Compromised bone marrow perfusion in osteoporosis. J Bone Miner Res. 2008;23:1068-1075.

56 Bloomfield SA, Hogan HA, Delp MD. Decreases in bone blood flow and bone material properties in aging Fischer-344 rats. Clin Orthop Relat Res. 2002;(396):248-257.

57 Prisby RD, Ramsey MW, Behnke BJ, Dominguez JM 2nd, Donato AJ, Allen MR, Delp MD. Aging reduces skeletal blood flow, endothelium-dependent vasodilation, and $\mathrm{NO}$ bioavailability in rats. J Bone Miner Res. 2007;22:1280-1288.

58 Griffith JF, Wang Y-XJ, Zhou H, Kwong WH, Wong WT, Sun Y-L, Huang Y, Yeung DKW, Qin L, Ahuja AT. Reduced bone perfusion in osteoporosis: likely causes in an ovariectomy rat model. Radiology. 2010;254:739-746.

59 London GM. Soft bone - hard arteries: a link? Kidney Blood Press Res. 2011;34:203-208.

60 De Schutter TM, Neven E, Persy VP, Behets GJ, Postnov AA, De Clerck NM, D'Haese PC. Vascular calcification is associated with cortical bone loss in chronic renal failure rats with and without ovariectomy: the calcification paradox. Am J Nephrol. 2011;34: 356-366.

61 Thompson B, Towler DA. Arterial calcification and bone physiology: role of the bone-vascular axis. Nat Rev Endocrinol. 2012;8:529-543.

62 Mizuno Y, Jacob RF, Mason RP. Advances in pharmacologic 
modulation of nitric oxide in hypertension. Curr Cardiol Rep. 2010;12:472-480.

63 Tsuda K, Nishio I, Masuyama Y. Bone mineral density in women with essential hypertension. Am J Hypertens. 2001;14:704-707.

64 Gotoh M, Mizuno K, Ono Y, Takahashi M. High blood pressure, bone-mineral loss and insulin resistance in women. Hypertens Res. 2005;28:565-570.

65 Giallauria F, Ling SM, Schreiber C, Maggio M, Shetty V, Muller D, Vigorito C, Ferrucci L, Najjar SS. Arterial stiffness and bone demineralization: the Baltimore longitudinal study of aging. Am J Hypertens. 2011;24:970-975.

66 Zhang Y-F, Wang Y-XJ, Griffith JF, Kwong WKM, Ma HT, Qin L, Kwok TCY. Proximal femur bone marrow blood perfusion indices are reduced in hypertensive rats: a dynamic contrastenhanced MRI study. J Magn Reson Imaging. 2009;30:1139-1144.

67 Vestergaard P, Rejnmark L, Mosekilde L. Hypertension is a risk factor for fractures. Calcif Tissue Int. 2009;84:103-111.

68 Rejnmark L. Cardiovascular drugs and bone. Curr Drug Saf. 2008; 3:178-184.

69 Wiens M, Etminan M, Gill SS, Takkouche B. Effects of antihypertensive drug treatments on fracture outcomes: a meta-analysis of observational studies. J Intern Med. 2006;260:350-362.

70 Reid IR. Effects of beta-blockers on fracture risk. J Musculoskelet Neuronal Interact. 2008;8:105-110.

71 Song HJ, Lee J, Kim Y-J, Jung S-Y, Kim HJ, Choi N-K, Park B-J. $\beta 1$ selectivity of $\beta$-blockers and reduced risk of fractures in elderly hypertension patients. Bone. 2012;51:1008-1015.

72 Hofbauer LC, Brueck CC, Singh SK, Dobnig H. Osteoporosis in patients with diabetes mellitus. J Bone Miner Res. 2007;22:13171328.

73 Oikawa A, Siragusa M, Quaini F, Mangialardi G, Katare RG, Caporali A, van Buul JD, van Alphen FPJ, Graiani G, Spinetti G, Kraenkel N, Prezioso L, Emanueli C, Madeddu P. Diabetes mellitus induces bone marrow microangiopathy. Arterioscler Thromb Vasc Biol. 2010;30:498-508.

74 Ohara T, Hirai T, Muro S, Haruna A, Terada K, Kinose D, Marumo S, Ogawa E, Hoshino Y, Niimi A, Chin K, Mishima M. Relationship between pulmonary emphysema and osteoporosis assessed by CT in patients with COPD. Chest. 2008;134:12441249.

75 Ferguson GT, Calverley PMA, Anderson JA, Jenkins CR, Jones PW, Willits LR, Yates JC, Vestbo J, Celli B. Prevalence and progression of osteoporosis in patients with COPD: results from the towards a revolution in COPD health study. Chest. 2009; 136:1456-1465.

76 Regan E, Jaramillo J. It's the fracture that matters -bone disease in COPD patients. COPD. 2012;9:319-321.

77 Miller RG, Segal JB, Ashar BH, Leung S, Ahmed S, Siddique S, Rice T, Lanzkron S. High prevalence and correlates of low bone mineral density in young adults with sickle cell disease. Am J Hematol. 2006;81:236-241.

78 Toumba M, Skordis N. Osteoporosis syndrome in thalassaemia major: an overview. J Osteoporos. 2010;2010:537673.

79 Kanis JA, Johansson H, Oden A, McCloskey EV. Assessment of fracture risk. Eur J Radiol. 2009;71:392-397.

80 Yoon V, Maalouf NM, Sakhaee K. The effects of smoking on bone metabolism. Osteoporos Int. 2012;23:2081-2092.

81 Spier SA, Delp MD, Meininger CJ, Donato AJ, Ramsey MW, Muller-Delp JM. Effects of ageing and exercise training on endothelium-dependent vasodilatation and structure of rat skeletal muscle arterioles. J Physiol. 2004;556:947-958.

82 Dominguez JM 2nd, Prisby RD, Muller-Delp JM, Allen MR, Delp MD. Increased nitric oxide-mediated vasodilation of bone resistance arteries is associated with increased trabecular bone volume after endurance training in rats. Bone. 2010;46:813-819.

83 Yao Z, Lafage-Proust M-H, Plouët J, Bloomfield S, Alexandre C, Vico L. Increase of both angiogenesis and bone mass in response to exercise depends on VEGF. J Bone Miner Res. 2004;19:14711480

84 Leblanc AD, Schneider VS, Evans HJ, Engelbretson DA, Krebs JM. Bone mineral loss and recovery after 17 weeks of bed rest. J Bone Miner Res. 1990;5:843-850.

85 Colleran PN, Wilkerson MK, Bloomfield SA, Suva LJ, Turner RT, Delp MD. Alterations in skeletal perfusion with simulated microgravity: a possible mechanism for bone remodeling. J Appl Physiol. 2000;89:1046-1054

86 Ding WG, Yan WH, Wei ZX, Liu JB. Difference in intraosseous blood vessel volume and number in osteoporotic model mice induced by spinal cord injury and sciatic nerve resection. J Bone Miner Metab. 2012;30:400-407.

87 Tu X, Rhee Y, Condon KW, Bivi N, Allen MR, Dwyer D, Stolina M, Turner $\mathrm{CH}$, Robling AG, Plotkin LI, Bellido T. Sost downregulation and local Wnt signaling are required for the osteogenic response to mechanical loading. Bone. 2012;50:209-217.

88 Kwon RY, Meays DR, Meilan AS, Jones J, Miramontes R, Kardos N, Yeh JC, Frangos JA. Skeletal adaptation to intramedullary pressure-induced interstitial fluid flow is enhanced in mice subjected to targeted osteocyte ablation. PloS One. 2012;7:e33336.

89 Qin YX, Kaplan T, Saldanha A, Rubin C. Fluid pressure gradients, arising from oscillations in intramedullary pressure, is correlated with the formation of bone and inhibition of intracortical porosity. J Biomech. 2003;36:1427-1437.

90 Kwon RY, Meays DR, Tang WJ, Frangos JA. Microfluidic enhancement of intramedullary pressure increases interstitial fluid flow and inhibits bone loss in hindlimb suspended mice. J Bone Miner Res. 2010;25:1798-1807.

91 Qin YX, Lam H, Ferreri S, Rubin C. Dynamic skeletal muscle stimulation and its potential in bone adaptation. J Musculoskelet Neuronal Interact. 2010;10:12-24.

92 Bergula AP, Huang W, Frangos JA. Femoral vein ligation increases bone mass in the hindlimb suspended rat. Bone. 1999; 24:171-177.

93 Bergula AP, Haidekker MA, Huang W, Stevens HY, Frangos JA Venous ligation-mediated bone adaptation is NOS 3 dependent. 
Bone. 2004;34:562-569.

94 Kelly PJ, Bronk JT. Venous pressure and bone formation. Microvasc Res. 1990;39:364-375.

95 Zorbas YG, Federenko YF, Naexu KA. Effect of hyperhydration on bone mineralization in physically healthy subjects after prolonged restriction of motor activity. Acta Astronaut. 1991;25: 727-731.

96 Schneider V, Oganov V, LeBlanc A, Rakmonov A, Taggart L, Bakulin A, Huntoon C, Grigoriev A, Varonin L. Bone and body mass changes during space flight. Acta Astronaut. 1995;36:463466.

97 Hanley DA, Brown JP, Tenenhouse A, Olszynski WP, Ioannidis G, Berger C, Prior JC, Pickard L, Murray TM, Anastassiades T, Kirkland S, Joyce C, Joseph L, Papaioannou A, Jackson SA, Poliquin S, Adachi JD. Associations among disease conditions, bone mineral density, and prevalent vertebral deformities in men and women 50 years of age and older: cross-sectional results from the Canadian Multicentre Osteoporosis Study. J Bone Miner Res. 2003;18:784-790.

98 Fritton SP, Weinbaum S. Fluid and Solute Transport in Bone: Flow-Induced Mechanotransduction. Annu Rev Fluid Mech. 2009; 41:347-374

99 Gurkan UA, Akkus O. The mechanical environment of bone marrow: a review. Ann Biomed Eng. 2008;36:1978-1991.

100 Wang L, Fritton SP, Weinbaum S, Cowin SC. On bone adaptation due to venous stasis. J Biomech. 2003;36:1439-1451.

101 Li W, Gardinier JD, Price C, Wang L. Does blood pressure enhance solute transport in the bone lacunar-canalicular system? Bone. 2010;47:353-359.

102 Caulkins C, Ebramzadeh E, Winet H. Skeletal muscle contractions uncoupled from gravitational loading directly increase cortical bone blood flow rates in vivo. J Orthop Res. 2009;27:651-656.

103 Winet H. A bone fluid flow hypothesis for muscle pump-driven capillary filtration: II. Proposed role for exercise in erodible scaffold implant incorporation. Eur Cell Mater. 2003;6:1-10; discussion 10-11.

Brinker MR, Lippton HL, Cook SD, Hyman AL. Pharmacological regulation of the circulation of bone. J Bone Joint Surg Am. 1990;72:964-975.

105 Tran MA. Effect of dopamine and apomorphine on bone circulation. J Pharmacol. 1981;12:417-426

106 Tran MA, Géral JP. The influence of some vasoactive drugs on bone circulation. Eur J Pharmacol. 1978;52:109-114

107 Dean MT, Wood MB, Vanhoutte PM. Antagonist drugs and bone vascular smooth muscle. J Orthop Res. 1992;10:104-111.

$\mathrm{Li} \mathrm{H}$, Förstermann U. Nitric oxide in the pathogenesis of vascular disease. J Pathol. 2000;190:244-254.

109 Fitzgerald SM, Bashari H, Cox JA, Parkington HC, Evans RG. Contributions of endothelium-derived relaxing factors to control of hindlimb blood flow in the mouse in vivo. Am J Physiol Heart Circ Physiol. 2007;293:H1072-H1082.

110 Wimalawansa SJ, De Marco G, Gangula P, Yallampalli C. Nitric oxide donor alleviates ovariectomy-induced bone loss. Bone. 1996; 18:301-304.

111 Wimalawansa SJ. Rationale for using nitric oxide donor therapy for prevention of bone loss and treatment of osteoporosis in humans. Ann N Y Acad Sci. 2007;1117:283-297.

112 Jamal SA, Hamilton CJ, Eastell R, Cummings SR. Effect of nitroglycerin ointment on bone density and strength in postmenopausal women: a randomized trial. JAMA. 2011;305:800807.

113 Jamal SA, Browner WS, Bauer DC, Cummings SR. Intermittent use of nitrates increases bone mineral density: the study of osteoporotic fractures. J Bone Miner Res. 1998;13:1755-1759.

114 Jamal SA, Hamilton CJ, Black D, Cummings SR. The effects of organic nitrates on osteoporosis: a randomized controlled trial [ISRCTN94484747]. Trials. 2006;7:10.

115 Jamal SA, Cummings SR, Hawker GA. Isosorbide mononitrate increases bone formation and decreases bone resorption in postmenopausal women: a randomized trial. J Bone Miner Res. 2004;19:1512-1517.

116 Khosla S. Is nitroglycerin a novel and inexpensive treatment for osteoporosis? JAMA. 2011;305:826-827.

117 Jamal SA, Reid LS, Hamilton CJ. The effects of organic nitrates on osteoporosis: a systematic review. Osteoporos Int. 2013;24:763770 .

118 Van't Hof RJ, Ralston SH. Nitric oxide and bone. Immunology. 2001;103:255-261.

119 Bakker AD, Huesa C, Hughes A, Aspden RM, van't Hof RJ Klein-Nulend J, Helfrich MH. Endothelial nitric oxide synthase is not essential for nitric oxide production by osteoblasts subjected to fluid shear stress in vitro. Calcif Tissue Int. 2013;92:228-239.

120 Chow JW, Fox SW, Lean JM, Chambers TJ. Role of nitric oxide and prostaglandins in mechanically induced bone formation. J Bone Miner Res. 1998;13:1039-1044.

121 Das-Gupta V, Williamson RA, Pitsillides AA. Expression of endothelial nitric oxide synthase protein is not necessary for mechanical strain-induced nitric oxide production by cultured osteoblasts. Osteoporos Int. 2012;23:2635-2647.

122 Pérez-Castrillón JL, De Luis DA, Duenas-Laita A. Are betablockers useful in the prevention of osteoporotic fractures? Eur Rev Med Pharmacol Sci. 2009;13:157-162.

123 Histing T, Marciniak K, Scheuer C, Garcia P, Holstein JH, Klein M, Matthys R, Pohlemann T, Menger MD. Sildenafil accelerates fracture healing in mice. J Orthop Res. 2011;29:867-873.

124 Gulhan I, Kebapcilar L, Alacacioglu A, Bilgili S, Kume T, Aytac B, Gunaydin R. Postmenopausal women with osteoporosis may be associated with high endothelin-1. Gynecol Endocrinol. 2009;25: 674-678.

125 Mestek ML, Weil BR, Greiner JJ, Westby CM, DeSouza CA, Stauffer BL. Osteopenia and endothelin-1-mediated vasconstrictor tone in postmenopausal women. Bone. 2010;47:542-545.

126 Zheng LW, Ma L, Cheung LK. Changes in blood perfusion and bone healing induced by nicotine during distraction osteogenesis. 
Bone. 2008;43:355-361.

127 Ma L, Zheng LW, Sham MH, Cheung LK. Uncoupled angiogenesis and osteogenesis in nicotine-compromised bone healing. J Bone Miner Res. 2010;25:1305-1313.

128 Wang HH, Drugge ED, Yen YC, Blumenthal MR, Pang PK. Effects of synthetic parathyroid hormone on hemodynamics and regional blood flows. Eur J Pharmacol. 1984;97:209-215.

129 Boushel R, Langberg H, Risum N, Kjaer M. Regulation of blood flow by prostaglandins. Curr Vasc Pharmacol. 2004;2:191-197.

130 Roche B, van den Bossche A, Normand M, Malaval L, Vico L, Lafage-Proust MH. Validated doppler measurement of mouse bone blood perfusion-response to age or ovariectomy differs with genetic background. Bone. 2013;55:418-426.

131 Moraes AN, Gouvêa SA, Gonçalves WLS, Romero WG, Moyses MR, Bissoli NS, Pires JGP, Abreu GR. Raloxifene reduces blood pressure in hypertensive animals after ovarian hormone deprivation. Basic Clin Pharmacol Toxicol. 2011;109:334-338.

132 Weinstein RS, Wan C, Liu Q, Wang Y, Almeida M, O’Brien CA, Thostenson J, Roberson PK, Boskey AL, Clemens TL, others. Endogenous glucocorticoids decrease skeletal angiogenesis, vascularity, hydration, and strength in aged mice. Aging Cell. 2010; 9:147-161.

133 Weinstein RS. Glucocorticoid-induced osteoporosis and osteonecrosis. Endocrinol Metab Clin North Am. 2012;41:595-611.

134 Collip JB, Clark EP. Further studies on the physiological action of parathyroid hormone. J Biol Chem. 1925;64:485-507.

135 Charbon GA. A rapid and selective vasodialtor effect of parathyroid hormone. Eur J Pharmacol. 1968;3:275-278.

136 Mok LL, Nickols GA, Thompson JC, Cooper CW. Parathyroid hormone as a smooth muscle relaxant. Endocr Rev. 1989;10: 420-436.

137 Qian J, Lorenz JN, Maeda S, Sutliff RL, Weber C, Nakayama T, Colbert MC, Paul RJ, Fagin JA, Clemens TL. Reduced blood pressure and increased sensitivity of the vasculature to parathyroid hormone-related protein (PTHrP) in transgenic mice overexpressing the PTH/PTHrP receptor in vascular smooth muscle. Endocrinology. 1999;140:1826-1833.

138 Yang R, Thomas GR, Bunting S, Ko A, Ferrara N, Keyt B, Ross J, Jin $H$. Effects of vascular endothelial growth factor on hemodynamics and cardiac performance. J Cardiovasc Pharmacol. 1996;27:838-844.
139 Gohin S, Chenu C, Pitsillides A, Arnett T, Marenzana M. Inhibition of PTH-induced vasorelaxation modulates its anabolic action. Presented at the European Calcified Tissue Society Conference ECTS 2013, Lisbon, Portugal. Bone Abstr. 2013;1:OC6.4.

140 Jee WS, Ma YF. The in vivo anabolic actions of prostaglandins in bone. Bone. 1997;21:297-304.

141 Vescini F, Grimaldi F. PTH 1-84: bone rebuilding as a target for the therapy of severe osteoporosis. Clin Cases Miner Bone Metab. 2012;9:31-36.

142 Poole KES, Reeve J. Parathyroid hormone-a bone anabolic and catabolic agent. Curr Opin Pharmacol. 2005;5:612-617.

143 Robling AG, Kedlaya R, Ellis SN, Childress PJ, Bidwell JP, Bellido $\mathrm{T}$, Turner $\mathrm{CH}$. Anabolic and catabolic regimens of human parathyroid hormone 1-34 elicit bone- and envelope-specific attenuation of skeletal effects in Sost-deficient mice. Endocrinology. 2011;152:2963-2975.

144 Tian XY, Zhang Q, Zhao R, Setterberg RB, Zeng QQ, Iturria SJ, Ma YF, Jee WSS. Continuous PGE2 leads to net bone loss while intermittent PGE2 leads to net bone gain in lumbar vertebral bodies of adult female rats. Bone. 2008;42:914-920.

145 Mendelsohn ME, Karas RH. The protective effects of estrogen on the cardiovascular system. N Engl J Med. 1999;340:1801-1811.

146 White RE. Estrogen and vascular function. Vascul Pharmacol. 2002;38:73-80

147 Mekraldi S, Lafage-Proust M-H, Bloomfield S, Alexandre C, Vico L. Changes in vasoactive factors associated with altered vessel morphology in the tibial metaphysis during ovariectomy-induced bone loss in rats. Bone. 2003;32:630-641.

148 Prisby RD, Dominguez JM 2nd, Muller-Delp J, Allen MR, Delp MD. Aging and estrogen status: a possible endotheliumdependent vascular coupling mechanism in bone remodeling. PloS One. 2012;7:e48564

149 Ruifrok WP, de Boer RA, Iwakura A, Silver M, Kusano K, Tio RA Losordo DW. Estradiol-induced, endothelial progenitor cellmediated neovascularization in male mice with hind-limb ischemia.Vasc Med. 2009;14:29-36.

150 Chan YC, Leung FP, Wong WT, Tian XY, Yung LM, Lau CW, Tsang SY, Yao X, Chen ZY, Huang Y. Therapeutically relevant concentrations of raloxifene dilate pressurized rat resistance arteries via calcium-dependent endothelial nitric oxide synthase activation. Arterioscler Thromb Vasc Biol. 2010;30:992-999. 